\title{
Measuring technical efficiency and its determinants among sweet potatoes farmers in Western Uganda
}

\author{
Midamba Dick Chune*, Alela Beatrice, Atukunda Bwesigye Obrine, Mary Kwesiga and \\ Ogei Kizito
}

\author{
Department of Agribusiness and Rural Development, Gulu University, P. O. Box 166, Gulu-Uganda.
}

Received 18 November, 2021; Accepted 5 January, 2022

\begin{abstract}
Sweet potato is one of the important staple food for majority of Ugandans. As such, it is depended on by many households. Reportedly, sweet potatoes production is low especially in Western Uganda. This may have been attributed to resource misallocation leading to some levels of efficiency or inefficiency. However, the current level of efficiency or inefficiency and its determinants in sweet potatoes production is unknown. As such, this study determined technical efficiency and its determinants among sweet potatoes farmers in western Uganda. Data were collected from 160 households using multistage and random sampling techniques. After data cleaning, 151 questionnaires were considered for the study. Data envelopment analysis was used to determine technical efficiency while Tobit regression model was used to analyse the determinants technical efficiency. The results showed that the mean technical efficiency stood at 55\%. Accordingly, household size, farm location, group membership and use of pesticides had a positive and statistically significant effect on technical efficiency while farm size and input prices had an inverse and statistically significant association with technical efficiency. To increase on sweet potatoes yields, farmers should be encouraged to form various groups where they could share production ideas, use pesticides for effective control of weeds and government should subsidise farm inputs to improve on affordability and timely acquisition.
\end{abstract}

Key words: Sweet potatoes, low yields, technical efficiency, subsidize, Uganda.

\section{INTRODUCTION}

Many sub-Sahara African (SSA) households depend on farming not only for food production but also for income (Diao et al., 2010; FAO, 2002, 2005; Imam and Kushwaha, 2013; Mozumdar, 2012; Pawlak and Kołodziejczak, 2020). The gross domestic product for most sub-Sahara African counties is boosted by agricultural production. This implies that agriculture has played a significant role in economic development (FAO, 2002). In Uganda, a country in East Africa, over $60 \%$ of the population are employed in agricultural related companies, organizations, industries and institutions (MAAIF, 2020). Nevertheless, household food security, which is the core part of human life, is attainable when massive investment in farming is undertaken since most of the foods consumed come from agriculture (Bamwesigye et al., 2020).

Sweet potato is one of the important traditional food crops in Uganda (MAAIF, 2020). Actually, besides maize,

*Corresponding author. E-mail: midambadick@gmail.com, Tel: +254 725682655.

Author(s) agree that this article remain permanently open access under the terms of the Creative Commons Attribution License 4.0 International License 
cassava and "matoke", sweet potato is one of the staple food in this country. Due to its importance, it is grown in all the districts in Uganda. However, the leading producers include Iganda, Nakasongola, Gulu and Kyenjojo districts producing over 270,853, 66,419, 61,732 and 40,148 tonnes, respectively (MAAIF, 2020). The advantage of sweet potatoes is that, unlike other crops such as maize and wheat, it requires less expenses when cooking as it only needs boiling or roasting and it will be ready for consumption. Actually, majority of Ugandans prefer consuming it raw (Tinyro and Mayanja, 2018). On value addition, sweet potato is used to make crisps, dried chips, bread, flour, noodles and animals feeds (Epeju and Rukundo, 2017). Besides, these significant benefits of sweet potato tubers, its leaves have been widely used as herbal drugs by majority of Africans. Among its herbal roles include heart health, anticoagulant, bone development, eye health, anti-mutagenic and antioxidant among other benefits. This implies that both sweet potato tubers and leaves are beneficial to humans (Epeju and Rukundo, 2017).

Despite the numerous benefits of sweet potato tubers and leaves, its production per unit area is low in Uganda (Bashaasha et al., 1995; Ebregt et al., 2004; Epeju and Rukundo, 2017). A study done by Kpaka et al. (2019) reported that sweet potatoes has a yield gap of 20.42 MT per hectare in Uganda. Similarly, Epeju and Rukundo (2017) reported that farmers were able to harvest 4,000 $\mathrm{kg}$ against the $30,000 \mathrm{~kg} / \mathrm{ha}$ which represents the optimal yield in Teso, Uganda. Many factors may have contributed to the low yields experienced in sweet potatoes production. One of the major causes of this is farm resource misallocation which results into inefficiency in production. Majority of small holder farmers depend on the trial and error methods of resource allocation resulting into either resource under-allocation or overallocation (Bamiro et al., 2012). In the long run, they suffer from huge losses. Land, labour and capital have been found to be the major resource in which decision have to be made, when these resources are well allocated, farmers achieve full efficiency (Okello et al., 2019).

In simple terms, technical efficiency implies that the judicious allocation of farm inputs and resources in such a way that it yields the highest output (Okello et al., 2019). As such, Farrell (1957) (the father of efficiency) revealed that when farmers allocate their farm resources in such a way that it yields maximum output, they achieve full technical efficiency. It is worth noting that achieving full technical efficiency is not only about obtaining maximum yields, but yielding the maximum output with zero input slacks (Gul et al., 2009; Ray, 2004). This has not been a common practice among farmers. The current levels of technical efficiency or inefficiency and its determinants among sweet potatoes farmers is unknown, a situation which does not guarantee maximum yields among the farmers. To fill this gap, this study therefore determined technical efficiency and its determinants among sweet potatoes farmers in Kiryandongo district, western Uganda. Information on the technical efficiency levels and its determinants is important in guiding the government areas for farmers' trainings in order to achieve full technical efficiency.

\section{LITERATURE REVIEW}

Many studies have been done on technical efficiency among different crops. For instance, Belete (2020) applied stochastic frontier analysis to determine technical efficiency among 234 maize farmers in Guji zone, Ethiopia. His results clearly showed that the farmers attained $69.03 \%$ level of technical efficiency, implying that they could reduce their inputs by $30.97 \%$ and would still produce the same quantity of maize. In additional to this, he found out that gender of the household head, age and access to credit had a negative and significant relation with technical efficiency while land size had a positive and significant influence on maize farming technical efficiency. Based on his results, he recommended that farmers trainings were important in order to achieve full technical efficiency.

Tampuli Abukari and Alemdar (2019) conducted a study aimed at determining technical and cost efficiency among maize farmers in Ghana. Data envelopment analysis, they reported that the mean technical, allocative and cost efficiency were 79,67 and $52 \%$, respectively. However, their results from stochastic frontier analysis showed that these farmers scored a mean of 77,27 and $21 \%$ technical, allocative and cost efficiencies. In addition to this, they also reported that farm size, marital status, education and years of continuous farming statistically influenced technical efficiency while cost efficiency was influenced by marital status, household structures and farming experience. They concluded that farmers are technically inefficient resulting into low yields.

Similarly, Jote et al. (2018) measured technical efficiency among 158 sweet potatoes farmers using Cobb-Douglas production function in southern Ethiopia. In their study, the minimum technical efficiency was $12.6 \%$ while the highest technically efficient farmer was at $93.7 \%$. They also reported that majority of the farmers achieved up to $66 \%$ technical efficiency. Farmer's age, education, livestock keeping had a positive and significant association with technical efficiency while farmers who had access to extension had lower technical efficiency than those with access to extension. They recommended relevant extension programs to fill in the efficiency gap.

Gaviglio et al. (2021) carried out a study on crops and livestock farms among 50 randomly sampled farmers in Milan, Italy to determine the level of technical efficiency and the farm productivity. In their study, two models were considered; constant and variable returns to scale DEA. 
Their results depicted that the mean technical efficiency under constant and variable returns to scale were 0.69 and 0.77 , respectively while the scale efficiency stood at 0.91 . They reported that in both models, the farmers were technically inefficient. They concluded that farmers could still increase their output by $23 \%$.

Additionally, Gaviglio et al. (2021) applied stochastic production frontier model to determine the level of technical efficiency among coffee farmers in Ethiopia. They also reported a mean technical efficiency of $88 \%$ with labour and farm size having negative and statistically significant association with technical efficiency while plot distance and female headed households had a positive and statistically significant effect on technical efficiency. They recommended policies targeting coffee yields such as training farmers on land and labour use. Similarly, Jeewanthi and Shantha (2021) reported that small scale tea farmers in Sri Lanka could increase their output by $21.56 \%$ without compromising the level of input, a situation implying that they were $78.44 \%$ technically efficient. They also reported that gender and access to extension were the determinants of technical efficiency.

Based on the findings of these literature, technical efficiency among different crops have been found at varied levels. However, one commonality in the cited literature is that they have reported some levels of inefficiency. On the factors affecting technical efficiency or the determinants of technical efficiency, these studies have reported different results calling for different policy implementations. It can therefore be concluded that the exact level of technical efficiency and its determinants among sweet potatoes farmers in Uganda is unknown. Additionally, this study was motivated by lack of literature of the technical efficiency and its determinants in Western Uganda.

\section{MATERIALS AND METHODS}

\section{Study area}

This study was carried out in Kiryandongo district in Western Uganda on November 2020. Specifically, Kigumba and Kiryandongo sub-counties were considered. In this district, farming is the main economic activity for majority of the households (UBOS, 2018). Besides farming, the population in this district engage in nonfarming activities such as motorbike riding, clothes selling, formal employment, brick making, shops and hotels among others. This district was considered due to the high number of refugees making land to be a major constraint. Additionally, the poverty line in this area is at $30 \%$ implying most of the households are poor (District and Plan., 2020). It has a total area of $3,621 \mathrm{~km}^{2}$ with a total population of 266,197 persons (UBOS, 2018).

\section{Sampling techniques}

Multistage and random sampling techniques was adopted in this study. After the purposive selection of this Kiryandongo district, two sub-counties were again purposively selected, namely: Kigumba and Kiryandongo sub-counties for data collection. In Kigumba,
Kigumba I and Kiigya villages were selected while in Kiryandongo sub-county, Kichwabugingo and Kyankende villages were considered. Finally, with the assistance from the district production officer, simple random sampling was used to obtain a total of 160 farmers for the study.

\section{Data collection}

Study enumerators were trained on data collection including ethical considerations acknowledged by Fleming and Zegwaard (2018), Gajjar (2013), and Polonsky and Waller (2021) during data collection. This was followed by pretesting the data collection tool on 30 farmers in Gulu district for three days to test for the relevance, clarity, validity and reliability of the data collection tool. The data collection tool captured socio-demographic characteristics (family size, gender, distance to the nearest trading centres, age, education level, access to credit, access to extension services among others) and production variables (land allocated to sweet potatoes, labour man days, quantity of sweet potatoes vine planted, use of pesticides to control diseases and pests), and output variables (quantity harvested, quantity consumed, quantity sold and the market price among others). After ascertaining that the data collection tool captured all the study variables accordingly and that it would give us reliable and valid data, we collected data from 160 sweet potatoes farmers through face-to-face interviews between the trained enumerators and the farmers using structured questionnaires. Because of the high illiteracy level among the farmers, the enumerators asked the questions and recorded the response from the farmers accordingly. Fortunately, all the questionnaires were well filled. After data collection, it was then entered into the Statistical Product and Service Solutions software (IBM SPSS) (Hejase and Hejase, 2013) template. Data cleaning was then done to eliminate outliers. Consequently, 151 questionnaires were considered as the final sample size.

\section{Data analysis}

According to Hejase and Hejase (2013), "descriptive statistics deals with describing a collection of data by condensing the amounts of data into simple representative numerical quantities or plots that can provide a better understanding of the collected data". Therefore, before applying the two-stage analysis, data were presented in the form of frequencies, percentages, proportions, and minimum values and standard deviations shown in Tables 1 and 2 . Furthermore, this study involved a two-step analysis. The first step used the data envelopment analysis to determine technical efficiency level while the second step applied the technical efficiency scores to Tobit regression model to determine the determinants of technical efficiency.

\section{Data envelopment analysis}

In order to determine technical efficiency, data was analysed using data envelopment analysis (DEA) developed by Cooper et al. (2011) and successfully applied by Ahmad et al. (2017) to determine firm efficiency in Pakistan. DEA is a non-parametric mathematical technique based on linear programming which has been widely used to measure the efficiency of different enterprises. The reason for selecting this model was because it can handle multiple inputs and outputs without biasness on any input or output (Abu, 2011). Specifically, this study employed input-oriented DEA under variables returns to scale. The choice of input orientation was attributed to the fact that many African small holder farmers have more powers over the quantities of inputs available to them for 
Table 1. Explanatory variables.

\begin{tabular}{lll}
\hline Explanatory variable & Measurement & Expected sign \\
\hline Household size & Household members & + - \\
Farm location & 1-Kiryandongo, 0-otherwise & $+/-$ \\
Gender of the household head & 1-Male, 0-otherwise & $+/-$ \\
Group membership & 1- Member, 0-otherwise & + \\
Input prices & Ugandan shillings & - \\
Farm size & Acres & $+/-$ \\
Distance to the trading centre & Kilometres & + - \\
Pesticides use & 1- used, 0-otherwise & + \\
\hline
\end{tabular}

Table 2. Farmer's characteristics.

\begin{tabular}{llcccc}
\hline Variable & Units of measurement & Mean & Standard deviation & Minimum & maximum \\
\hline Age & Years & 41.06 & 12.61 & 18.00 & 87.00 \\
Household size & Number & 7.72 & 3.34 & 1.00 & 20.00 \\
Education & Years & 6.50 & 4.70 & 0.00 & 8.00 \\
Farm size & Acres & 4.20 & 1.80 & 1.00 & 10.00 \\
Sweet potatoes farm size & Acres & 0.46 & 0.28 & 0.13 & 2.00 \\
Farming experience & Years & 16.60 & 10.60 & 1.00 & 45.00 \\
Distance to the market & Kilometres & 2.90 & 1.63 & 0.00 & 8.00 \\
Gender & Male & 0.72 & 0.45 & 0.00 & 1.00 \\
Access to credit & Has access & 0.72 & 0.45 & 0.00 & 1.00 \\
Access to extension & Has extension & 0.84 & 0.37 & 0.00 & 1.00 \\
Group membership & Member & 0.79 & 0.41 & 0.00 & 1.00 \\
\hline
\end{tabular}

production (Tipi et al., 2009).

According to Yilmaz and Yurdusev (2011), variable returns to scale under input orientation DEA model is specified as:

\section{$\operatorname{Min}_{\theta \lambda} \quad \theta$}

$$
\begin{aligned}
& \text { Subject to }-\mathrm{y}_{\mathrm{i}}+\mathrm{Y} \lambda \geq 0 \\
& \theta \mathrm{x}_{\mathrm{i}}-\mathrm{X} \lambda \geq 0 \\
& \mathrm{~N} 1^{\prime}=1 \\
& \lambda=0
\end{aligned}
$$

$$
\text { where, } \mathrm{i}=1,2,2,3 \ldots \ldots \mathrm{i}
$$

where $\mathrm{N} 1^{J}$ represents a convexity constant, $\lambda$ represents the $\mathrm{N} \times$ 1 vector of constants, $\mathrm{X}$ represents the input matrix, $\mathrm{Y}$ represents the output matrix, $y_{i}$ represents a vector $(k \times 1)$ output and $x_{i}$ represents a vector $(k \times 1)$ input. The number of farmers is defined as $i$ for this study. For every decision-making unit, there was $\mathrm{N}$ inputs $(\mathrm{N}=3$, that is, land, labour man days and sweet potatoes vines) and $M$ outputs ( $M=1$, sweet potatoes quantity harvested). The value $\theta$ represents the technical efficiency score ranging from 0 to 1. According to Farrell (1957), if the value of $\theta$ is 1 , it indicates that the farmer is fully efficient. However, any value less than 1 indicates technical inefficiency.

\section{Tobit model}

The technical efficiency scores obtained in data envelopment analysis above were now considered as the dependent variable in Tobit model since they were having upper and lower limits ( 0 and 1 , respectively). Consequently, they were regressed against the determinants of technical efficiency obtained from literature review. According to Tobin (1958), Tobit regression model is specified as:

$\mathrm{Y}_{\mathrm{i}}=\beta \mathrm{X}_{\mathrm{i}}+\varepsilon_{\mathrm{i}}$

The model is then modified to explain the determinants of technical efficiency as:

$$
\begin{aligned}
& \mathrm{Y}_{\mathrm{i}}=\mathrm{Y}_{\mathrm{i}}^{*} \text { if } \mathrm{Y}_{\mathrm{i}}^{*}>0 \\
& \mathrm{Y}_{\mathrm{i}}=0, \text { if } \mathrm{Y}^{*} \leq 0 \\
& \mathrm{Y}^{*}=\beta_{0}+\beta_{1}\left(\mathrm{X}_{1}\right)+\varepsilon_{1}
\end{aligned}
$$

where $\mathrm{Y}_{\mathrm{i}}^{*}$ represents the dependent variable (technical efficiency), $\beta_{0}$ represents the coefficient of intercept, $\beta_{1}$ represents the regression coefficient of estimates to be determined, $\mathrm{X}_{\mathrm{i}}$ represents the determinants of technical efficiency such as household size, farm location, gender of the household head, group membership, input prices, farm size, distance to the nearest trading centers and use of pesticides as illustrated in Table 1 , while $\mathcal{G}_{i}$ represents the 
stochastic error term assumed to be normally distributed.

\section{RESULTS AND DISCUSSION}

\section{Farmers' demographics}

Table 2 presents socio-demographic features of the farmers. Based on the results, the farmers' mean age was 41.06 years with 16 years of farming experience; this implies that they were in their active ages of production. They had a mean household size of 8 household members. This showed that massive investment in farming is necessary in order to provide food for the growing household size. Accordingly, the farmers spent a mean of 6.50 years in school. This clearly showed that majority of the farmers attained up to primary education level. On land holdings, these smallholder farmers had a mean of 4.20 acres of land. However, they allocated approximately $11 \%$ of this land to sweet potatoes while the rest was allocated to other crops. This allocation plan is common among African small holder farmers as they try to minimize their risks by producing as many crops as possible. Farmers were located $2.9 \mathrm{~km}$ away from trading centres, a situation depicting that accessing farm inputs was easy. The results further showed that $72 \%$ of the farmers were males. This is also common among smallholder farmers since many households are male headed. As such, they have the obligations to invest in food crops production to feed their families. On institutional arrangements, 72,84 and $79 \%$ of the farmers had access to credit, extension services and were members to farmers groups, respectively.

\section{Descriptive statistics for the variables used in technical efficiency analysis}

Table 3 presents descriptive statistics for the variables used in DEA for the technical efficiency analysis. These include the inputs and the outputs. For the output, we considered sweet potatoes yields in kilograms. Its mean stood at $417.32 \mathrm{~kg}$. Indeed, the results showed that the yields from sweet potatoes are generally low. On the other hand, the inputs included land, labour man days and sweet potatoes vines measured in acres, days and $50-\mathrm{kg}$ sack, respectively. The farmers used an average of 0.46 acres of land, 36.84 labour man days and 6.26 of 50 $\mathrm{kg}$ sack of sweet potatoes vines for their production.

\section{Technical efficiency}

Table 4 and Figure 1 present the results from DEA on technical efficiency distribution. Accordingly, the results showed that the mean technical efficiency stood at 55\%. This implies that up to $45 \%$ of the output was lost. In terms of the distribution of technical efficiency levels,
$73.51 \%$ of the farmers achieved up to $60 \%$ technical efficiency. This implies that indeed the farmers are misappropriating their farm resources leading to the $45 \%$ inefficiency in sweet potatoes production. These results are in line with previous studies. For instance, Joseph (2014) reported a mean technical efficiency of $64 \%$ with a minimum and maximum technical efficiency of 19 and $93 \%$, respectively among the farmers in Kogi State, Nigeria. Other studies which have reported technical inefficiencies among small holder farmers (Ashraf et al., 2019; Belete, 2020; Jote et al., 2018; Sherzod et al., 2018; Tampuli Abukari and Alemdar, 2019; Tipi et al., 2010; Tsoho et al., 2012; Wang et al., 2017; Gul et al., 2009) among others.

\section{Returns to scale}

The results depicted in Table 5 showed that $92.72 \%$ of the farmers were operating under the increasing returns to scale while the rest under decreasing and increasing returns to scale. This implies that most of the farmers were operating under the sub-optimal conditions. Based on this, they could still produce more output before arriving at the decreasing returns to scale. This agrees to the results reported by Gul et al. (2009), who found out that $72 \%$ of small holder farmers were operating under the increasing returns to scale, implying that there was room to increase the yield. However, Tipi et al. (2010) reported that only $20 \%$ of the rice farmers in Turkey were operating under the constant returns to scale.

\section{Determinants of technical efficiency}

Table 6 presents determinants of technical efficiency. Based on the results, household size had a positive and statistically significant $(p<0.05)$ association with technical efficiency. Increasing household size by a unit would result into an increase in technical efficiency by $9.7 \%$. Many African countries depend on family labour as the primary source of labour for their farms (Gollin, 2014). As such, families with many household members were better off in terms of labour allocation for sweet potatoes production. On the other hand, families with few household members depended on hired labour which is paid and hence reducing the technical efficiency. This contradicts the findings from Joseph (2014) who observed that households with many family members had lower technical efficiency than those with few members. Additionally, Tan et al. (2010) reported a negative and statistically significant relationship between family size and technical efficiency among rice producers in Southern China.

There was a positive and statistically significant $(p<0.10)$ influence of farm location on sweet potatoes production technical efficiency. Farmers were categorized into two locations: Kigumba and Kiryandongo sub- 
Table 3. Descriptive statistics for the inputs and outputs.

\begin{tabular}{llcccc}
\hline Variable & Unit & Mean & Standard deviation & Minimum & Maximum \\
\hline Output & & & & & \\
Sweet potatoes yield & Kilograms & 417.32 & 278.22 & 150.00 & $2,000.00$ \\
& & & & & \\
Inputs & Acres & 0.46 & 2.80 & 0.13 & 2.00 \\
Land & Days & 36.84 & 15.04 & 10.00 & 60.00 \\
Labour man days & 6.26 & 4.15 & 0.50 & 22.00 \\
Sweet potatoes vines & 50-kg sack & 6.00 \\
\hline
\end{tabular}

Table 4. Technical efficiency distribution.

\begin{tabular}{lccc}
\hline Technical distribution & Frequency & Percentage & Cumulative percentage \\
\hline$\leq 0.50$ & 53 & 35.10 & 35.10 \\
$0.51-0.60$ & 58 & 38.41 & 73.51 \\
$0.61-0.70$ & 13 & 8.61 & 82.12 \\
$0.71-0.80$ & 10 & 6.62 & 88.74 \\
$0.81-0.90$ & 4 & 2.65 & 91.39 \\
$\geq 0.91$ & 13 & 8.61 & 100.00 \\
\cline { 1 - 1 } Other statistics & Efficiency & & \\
\cline { 1 - 2 } Least efficient farmer & 0.19 & & \\
Mean efficiency & 0.55 & & \\
Most efficient farmer & 1.00 & & \\
\hline
\end{tabular}

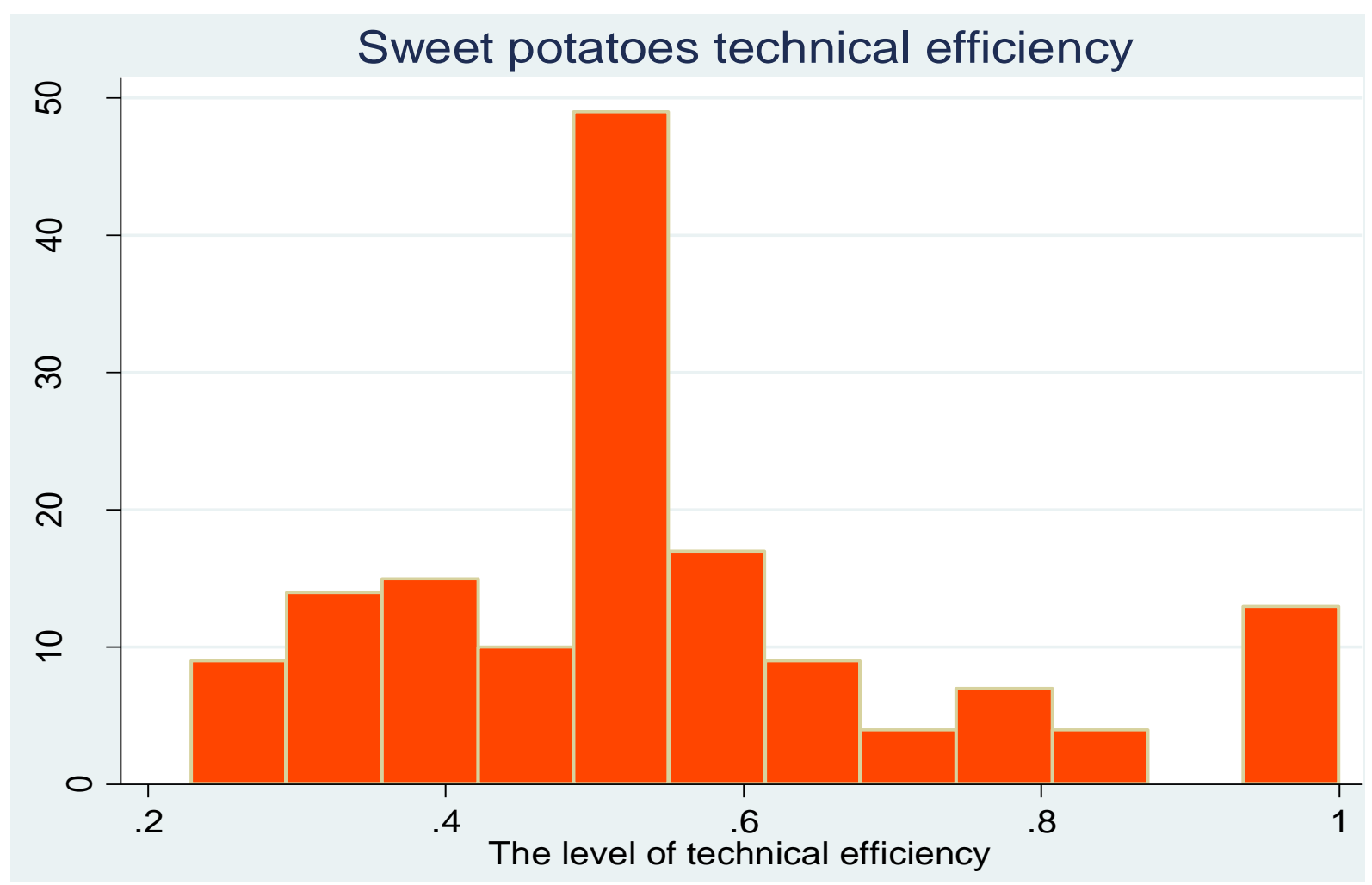

Figure 1. Illustration of sweet potatoes technical efficiency. 
Table 5. Returns to scale.

\begin{tabular}{lcc}
\hline Returns to scale & Number of farmers & Percentage \\
\hline Decreasing returns to scale & 06 & 3.97 \\
Constant returns to scale & 05 & 3.31 \\
Increasing returns to scale & 140 & 92.72 \\
Total & 151 & 100.00 \\
\hline
\end{tabular}

Table 6. Determinants of technical efficiency.

\begin{tabular}{lccc}
\hline Variable & Coefficient & Standard errors & P>t \\
\hline Household size & 0.0973227 & 0.0388945 & $0.013^{\star *}$ \\
Farm location (Kiryandongo) & 0.0634183 & 0.0374476 & $0.093^{*}$ \\
Gender of the household head (Male) & -0.0302465 & 0.0401443 & 0.452 \\
Group membership & 0.1016164 & 0.0373646 & $0.007^{* * *}$ \\
Input prices & -0.1272702 & 0.0363520 & $0.001^{* * *}$ \\
Farm size & -0.2617965 & 0.0667440 & $0.000^{* * *}$ \\
Distance to the trading centre & -0.0148203 & 0.0109470 & 0.178 \\
Pesticides use & 0.1180868 & 0.0516731 & $0.024^{* \star}$ \\
Constant & 2.1993810 & 0.5431927 & $0.000^{* * *}$ \\
LR chi & \\
Pseudo $(13)$ & & 58.19 & \\
Log likelihood $^{2}$ & & 0.8261 & \\
Prob>Chi & & -6.1224 & \\
$\mathrm{~N}$ & & 0.0000 & \\
\hline
\end{tabular}

${ }^{*},{ }^{* *}$ and ${ }^{* * *}$ means statistical significance at 10,5 and $1 \%$, respectively.

counties. Farmers located in Kiryandongo sub-county had $6.34 \%$ higher technical efficiency than those in Kigumba. This was attributed to the fact that Kiryandongo sub-county is the headquarters of Kiryandongo district. As such, farmers in Kiryandongo sub-county could access farm trainings, agricultural information and consultants easily than their counterparts. This contributed to increased technical efficiency for the farmers in Kiryandongo sub-county than those in Kigumba. This is in line with the findings by Okello et al. (2019) who found out that farmers in Gulu had higher allocative efficiency than their counterparts in Amuru district. Additionally, Adhikari et al. (2021) and Tsoho et al. (2012) also found out that farm location had a significant association with technical, allocative and economic efficiency among different crops.

Accordingly, the results (Table 6) showed that farmers belonging to agricultural groups had $10.16 \%$ higher technical efficiency than their fellows who did not belong to the groups. This implies that group membership had a positive and significant $(p<0.01)$ relationship with technical efficiency among the farmers. Belonging to farm groups helps farmers share ideas, save money, organize farm trainings, access adoption practices, among other benefits. These increase technical efficiency among the farmers. As such, farmers belonging to agricultural groups have a higher technical efficiency than those who were non-group members. This is in line with the findings reported by Ma et al. (2018), who reported a positive and significant association between group membership and technical efficiency among apple farmers in China. Similarly, Wongnaa and Awunyo-Vitor (2018) depicted a positive influence of farmers group membership on technical efficiency among maize farmers in Ghana. However, it contradicts findings reported by Hakim et al. (2021) that groups membership had no significant effect on technical efficiency among Indonesian farmers.

Input prices had a negative and significant association with technical efficiency. Holding other factors constant, increasing input prices would reduce overall technical efficiency by $12.72 \%$. This implies that high input prices would result into technical inefficiency. Input prices consisted of the prices of sweet potatoes vines and pesticides. The negative influence of input prices on technical efficiency was attributed to the fact that during the planting season, the prices of farm inputs is always higher. This study was done just immediately after majority of the farmers had cleared their lands and were now waiting for the planting rains. As such, there was a high demand of sweet potatoes' vines and pesticides 
during this season. A study done by Lindawati et al. (2018) reported a similar finding where by the prices of farm inputs negatively and statistically influenced rice and livestock farming system in Indonesia, implying that high input prices would result into technical inefficiency. Similarly, a study done by Briner and Finger (2013) reported a negative association between input prices and resource use efficiency in Swiss dairy production system.

The results further showed a negative and statistically significant $(p<0.01)$ relationship between technical efficiency and farm size. A unit increase in farm size, while holding other variables constant would reduce sweet potatoes technical efficiency by $26.18 \%$. The negative influence of farm size on sweet potatoes technical efficiency was attributed to the labour availability and use among the farmers. Sweet potatoes production is labour demanding yet the farmers' main source of labour was their respective household members. As such, those who had large portions of land were less technically efficient than those who had small portions of land. This agrees to the findings reported by Okello et al. (2019) who reported a negative influence of farm size on allocative efficiency among cassava and rice farmers in Gulu and Amuru districts, Uganda. However, it contradicts the findings reported by Belete (2020), who reported a negative association between land size and technical efficiency among maize farmers in Guji zone. Similarly, Tipi et al. (2010) reported a positive influence of farm size on technical efficiency among rice farmers in Turkey.

Lastly, the results showed that farmers who used pesticides had $11.80 \%$ higher technical efficiency than those who did not use pesticides. Just like other crops, sweet potatoes have pests and diseases which when not properly and timely controlled, would result into crops destruction, quality and quantity reduction, leading to heavy losses. In some extreme cases, pests and diseases would result into unsafe and poisonous food. In this study, farmers reported that their sweet potatoes were attacked by sweet potatoes feathery mottle virus and sweet potato chlorotic stunt virus at some points during the production cycle. However, due to financial constraints and food demand, majority of the farmers did not use pesticides in their farms. As such, those who used pesticides to control these diseases had higher technical efficiency. These results contradict the findings reported by Ayu and Aulia (2018) who reported that farmers who used pesticides were not technically efficient, they also acknowledged that these farmers were not using the right quantities of pesticides for tomatoes production.

\section{CONCLUSION AND RECOMMENDATION}

This study was motived by lack of literature on the exact level of technical efficiency and its determinants among sweet potatoes farmers in western Uganda. As a result, this study was done in Kiryandongo district on 160 farmers using multistage and random sampling techniques to determine technical efficiency and its determinants among sweet potatoes farmers. DEA and Tobit model were used to determine technical efficiency and its determinants, respectively. The results showed that farmers harvested a mean of $417.32 \mathrm{~kg}$ of sweet potatoes, which was generally low. They were 55\% technically efficient, implying that they could increase their yields by $45 \%$ without compromising the input levels. The results also indicated that majority of the farmers were operating under the increasing returns to scale, implying that they had not reached the optimum output level. Household size, farm location, membership to farmers groups, and use of pesticides had a positive and statistically significant influence on sweet potatoes technical efficiency while farm size and input prices showed a negative and statistically significant influence on technical efficiency. This study therefore concluded that sweet potatoes farmers in western Uganda are technically inefficient and the determinants of technical efficiency include household size, farm location, group membership, use of pesticides, farm size and input prices.

Based on the results of this study, we recommended that farmers should be encouraged to form agricultural groups which share ideas related to farm production that helps them boost their yields. Additionally, subsidizing farm inputs would help farmers' access them easily and timely resulting into increased yields, as such, we recommended that the Ministry of Agriculture, Animal Husbandry and Fisheries should subsidize farm inputs to help the farmers increase their yields. Lastly, this study recommended that farmer should be trained and encouraged to use pesticides to control the pests and diseases in their farms.

\section{CONFLICT OF INTERESTS}

The authors have not declared any conflict of interests.

\section{ACKNOWLEDGEMENTS}

The authors appreciate the support of the Regional Universities Forum for Capacity Building in Agriculture (RUFORUM) for funding the study through the Transforming African Agricultural Universities to meaningfully contribute to Africa's growth and development (TAGDev) funded by Mastercard Foundation.

\section{REFERENCES}

Abu O (2011). Fertilizer Usage and Technical Efficiency of Rice Farms under Tropical Conditions: A Data Envelopment Analysis (DEA). Journal of Agricultural Sciences 2(2):83-87. 
Adhikari SP, Ghimire YN, Timsina KP, Subedi S, Kharel M (2021). Technical efficiency of wheat growing farmers of Nepal. Journal of Agriculture and Natural Resources 4(2):246-254.

Ahmad MF, Ishtiaq M, Hamid K, Usman Khurram M, Nawaz A (2017). Data Envelopment Analysis and Tobit Analysis for Firm Efficiency in Perspective of Working Capital Management in Manufacturing Sector of Pakistan. International journal of Economics and Financial 7(2):706-713.

Ashraf M, Qasim M, Gul F (2019). Impact of Education on Farmers Earning: A House Hold Survey Data Analysis. International Research Journal of Applied Sciences Research pp. 2663-5585.

Ayu FS, Aulia D (2018). Technical efficiency of pesticide application on tomato, Chinese cabbage and cauliflower in simpang empat subdistrict Karo Regency. E3S Web of Conferences P 52. Available at: https://doi.org/10.1051/e3sconf/20185200045

Bamiro OM, Afolabi M, Daramola F (2012). Enterprise Combinations in Cassava Based Food Crop Farming System in Nigeria: Evidence from Ogun State. Greener Journal of Agricultural Sciences 2(1):013020.

Bamwesigye D, Doli A, Adamu KJ, Mansaray SK (2020). A review of the political economy of agriculture in Uganda: Women, property rights, and other challenges. Universal Journal of Agricultural Research 8(1):1-10. Available at: https://doi.org/10.13189/ujar.2020.080101

Bashaasha B, Mwanga ROM, Obwoya CO, Ewell PT (1995). Sweetpotato in the Farming and Food Systems of Uganda: A Farm Survey Repor by: International Potato Center (CIP) and National Agricultural Research Organization (NARD). Available at: http://citeseerx.ist.psu.edu/viewdoc/download?doi=10.1.1.534.7117\&r ep $=$ rep $1 \&$ type $=$ pdf

Belete AS (2020). Analysis of technical efficiency in maize production in Guji Zone: stochastic frontier model. Agriculture and Food Security 9(1):1-15. Available at: https://doi.org/10.1186/s40066-020-00270-w

Briner S, Finger R (2013). The effect of price and production risks on optimal farm plans in Swiss dairy production considering 2 different milk quota systems. Journal of Dairy Science 96(4):2234-2246. Available at: https://doi.org/10.3168/jds.2012-6086

Cooper WW, Seiford LM, Zhu J (2011). Data envelopment analysis: History, models, and interpretations. InHandbook on data envelopment analysis pp. 1-39. Available at: https://doi.org/10.1007/978-1-4419-6151-8_1

Diao X, Hazell P, Thurlow J (2010). The Role of Agriculture in African Development. World Development 38(10):1375-1383.

District K, Plan D (2020). Kiryandongo District Development Plan for FY 2015/2016-2019/2020.

Ebregt E, Struik PC, Abidin PE, Odongo B (2004). Farmers' information on sweet potato production and millipede infestation in north-eastern Uganda. Pest incidence and indigenous control strategies. NJAS Wageningen Journal of Life Sciences 52(1):69-84.

Epeju WF, Rukundo PM (2017). Food Security and Income through Sweet Potato Production in Teso, Uganda. Sustainable Agriculture Research 7(1):146.

Food and Agriculture Organization (FAO) (2002). The Role of Agriculture in the Development of Least-developed Countries and their Integration into the World Economy. Fao, 7. Available at: http://www.fao.org/3/a-y3997e.pdf

Food and Agriculture Organization (FAO) (2005). The state of food insecurity in the world: Eradicating world hunger - Key to achieving the Millennium Development Goals. In Food and Agriculture Organization of the United Nations. Available at: http://www.fao.org/icatalog/inter-e.htmPublished

Farrell MJ (1957). The Measurement of Productive Efficiency. Journal of the Royal Statistical Society 120(3):253-290.

Fleming J, Zegwaard KE (2018). Methodologies, methods and ethical considerations for conducting research in work-integrated learning. International Journal of Work-Integrated Learning 19(3):205-213.

Gajjar NB (2013). Ethical Consideration in Research. International Journal for Research in Education 2(7):8-15.

Gaviglio A, Filippini R, Madau FA, Marescotti ME, Demartini E (2021). Technical efficiency and productivity of farms: A periurban case study analysis. Agricultural and Food Economics 9(1):1-8.

Gollin D (2014). Smallholder agriculture in Africa. IIED Working Paper.
IIED, London, October, 1-20.

Gul M, Koc B, Dagistan E, Akpinar MG, Parlakay O (2009). Determination of technical efficiency in cotton growing farms in Turkey: A case study of Cukurova region. African Journal of Agricultural Research 4(10):944-949.

Hakim R, Haryanto T, Sari DW (2021). Technical efficiency among agricultural households and determinants of food security in East Java, Indonesia. Scientific Reports 11(1):1-9.

Hejase AJ, Hejase HJ (2013). Research Methods: A Practical Approach for Business Students (2nd edition). Philadelphia PA, USA: Masadir Incorporated $272 \mathrm{p}$.

Imam E, Kushwaha SPS (2013). Habitat suitability modelling for Gaur (Bos gaurus) using multiple logistic regression, remote sensing and GIS. Journal of Applied Animal Research 41(2):189-199.

Jeewanthi DGM, Shantha AA (2021). The Technical Efficiency of Smallscale Tea Plantation in Sri Lanka. Asian Journal of Management Studies 1(1):128.

Joseph Al (2014). Analysis of the Determinants of Technical Efficiency among Some Selected Small Scale Farmers in Kogi State. International Journal of African and Asian Studies- An Open Access International Journal 5:24-30.

Jote A, Feleke S, Tufa A, Manyong V, Lemma T (2018). Assessing the efficiency of sweet potato producers in the southern region of ethiopia. Experimental Agriculture 54(4):491-506.

Kpaka C, Gugerty MK, Anderson CL (2019). Sweet Potato Value Chain: Uganda. Gates Open Research 3(652):652.

Lindawati L, Kusnadi N, Kuntjoro SU, Swastika DKS (2018). The Impact of Input and Output Prices on The Household Economic Behavior of Rice-Livestock Integrated Farming System (Rlifs) and Non Rlifs Farmers The Impact of Input and Output Prices on The House. International Conference on Agriculture, Environment, and Food Security pp. 1-9. Available at: doi :10.1088/1755-1315/122/1/012020

Ma W, Renwick A, Yuan P, Ratna N (2018). Agricultural cooperative membership and technical efficiency of apple farmers in China: An analysis accounting for selectivity bias. Food Policy 81:122-132. Available at: https://doi.org/10.1016/j.foodpol.2018.10.009

Ministry of Agriculture, Animal Industry and Fisheries (MAAIF) (2020). The Republic of Uganda Ministry of Agriculture, Animal Industry and Fisheries, Draft Anual Report pp. 1-150.

Mozumdar L (2012). Agricultural productivity and food security in the developing world. Bangladesh Journal of Agricultural Economics 35(1-2):53-69.

Okello DM, Bonabana-Wabbi J, Mugonola B (2019). Farm level allocative efficiency of rice production in Gulu and Amuru districts, Northern Uganda. Agricultural and Food Economics 7(1):1-9. Available at: https://doi.org/10.1186/s40100-019-0140-x

Pawlak K, Kołodziejczak M (2020). The role of agriculture in ensuring food security in developing countries: Considerations in the context of the problem of sustainable food production. Sustainability 12(13). Available at: https://doi.org/10.3390/su12135488

Polonsky M, Waller D (2021). Designing and Managing a Research Project: A Business Student's Guide. Designing and Managing a Research Project: A Business Student's Guide pp. 53-76. Available at: https://doi.org/10.4135/9781544316499

Ray SC (2004). Data envelopment analysis: Theory and techniques for economics and operations research. Data Envelopment Analysis: Theory and Techniques for Economics and Operations Research pp. 1-353. Available at: https://doi.org/10.1017/CBO9780511606731

Sherzod B, Kim KR, Lee SH (2018). Agricultural transition and technical efficiency: An empirical analysis of wheat-cultivating farms in Samarkand Region, Uzbekistan. Sustainability 10(9):3232.

Tampuli AB, Alemdar T (2019). Measuring the Technical and Cost Efficiencies of Maize Farming in the Northern Region of Ghana: Deterministic and Stochastic Approaches. Agricultural Social Economic Journal 19(01):47-64.

Tan S, Heerink N, Kuyvenhoven A, Qu F (2010). Impact of land fragmentation on rice producers' technical efficiency in South-East China. NJAS - Wageningen Journal of Life Sciences 57(2):117-123.

Tinyro E, Mayanja S (2018). State Of Knowledge Report: Sweet Potato - Uganda $49 \mathrm{p}$.

Tipi T, Yildiz N, Nargeleçekenler M, Çetin B (2009). Measuring the technical efficiency and determinants of efficiency of rice (Oryza 
sativa) farms in marmara region, Turkey. New Zealand Journal of Crop and Horticultural Science 37(2):121-129.

Tipi T, Yildiz N, Nargeleçekenler M, Çetin B (2010). Measuring the technical efficiency and determinants of efficiency of rice (Oryza sativa) farms in Marmara region, Turkey. New Zealand Journal of Crop and Horticultural Science P 671. Available at: https://doi.org/10.1080/01140670909510257

Tobin J (1958). Estimation of Relationships for Limited Dependent Variables. Econometrica 26(1):24-36.

Tsoho BA, Omotesho OA, Salau SA, Adewumi MO (2012). Determinants of Technical, Allocative and Economic Efficiencies among Dry Season Vegetable Farmers in Sokoto State, Nigeria. Journal of Agricultural Sciences 3(2):113-119.

Uganda Bureau of Statistics (UBOS) (2018). Uganda Bureau of Statistics. The 2018 Statistical report $345 \mathrm{p}$.

Wang Y, Shi L, Zhang H, Sun S (2017). A data envelopment analysis of agricultural technical efficiency of Northwest Arid Areas in China. Frontiers of Agricultural Science and Engineering 4(2):195-207.
Wongnaa CA, Awunyo-Vitor D (2018). Achieving sustainable development goals on no poverty and zero hunger: Does technical efficiency of Ghana's maize farmers matter? Agriculture and Food Security $7(1): 1-13$.

Yilmaz B, Yurdusev MA (2011). Use of data envelopment analysis as a multi criteria decision tool - A case of irrigation management. Mathematical and Computational Applications 16(3):669-679. 